archives-ouvertes

\title{
Arabization and linguistic domination: Berber and Arabic in the North of Africa
}

\author{
Mohand Tilmatine
}

\section{To cite this version:}

Mohand Tilmatine. Arabization and linguistic domination: Berber and Arabic in the North of Africa. Language Empires in Comparative Perspective, DE GRUYTER, pp.1-16, 2015, Koloniale und Postkoloniale Linguistik / Colonial and Postcolonial Linguistics 978-3-11-040836-2. hal-02182976

\section{HAL Id: hal-02182976 \\ https://hal.archives-ouvertes.fr/hal-02182976}

Submitted on 14 Jul 2019

HAL is a multi-disciplinary open access archive for the deposit and dissemination of scientific research documents, whether they are published or not. The documents may come from teaching and research institutions in France or abroad, or from public or private research centers.
L'archive ouverte pluridisciplinaire HAL, est destinée au dépôt et à la diffusion de documents scientifiques de niveau recherche, publiés ou non, émanant des établissements d'enseignement et de recherche français ou étrangers, des laboratoires publics ou privés. 


\title{
MOHAND TILMATINE \\ Arabisation and linguistic domination: Berber and Arabic in the North of Africa
}

\begin{abstract}
Due to Arab territorial expansion in the Middle Ages and the diffusion of Islam and the Qur'an, Arabic_spread across all North Africa. After the North African countries became independent in the twentieth century, the ideological choices of these countries led to a policy of Arabisation of the Berberophones of Morocco, Algeria and Libya. While those of Tunisia have practically disappeared, the surviving Amazigh populations try to resist and save their language by claiming linguistic rights. In addition, the absolute domination of Arabic, as it was previously the case of French, as a "language of bread" (Native Language) inculcated/instilled in speakers of indigenous languages is typically reflected $\mathrm{r}$ in this kind of situation: the hate of oneself and linguistic alienation. As a result of the ideological choices made after independence, repressive laws were passed to force Arabisation upon local populations and to break their resistance. The law on Arabisation in Algeria illustrates perfectly this linguistic policy of repression and constitutes therefore the object of this contribution and a case study in this sense.
\end{abstract}

Keywords: Berber, Arabisation, North Africa, Algeria, Identity

Mohand Tilmatine: Facultad de Filosofía y Letras, Departamento de Filología, Estudios Amaziges (Bereberes), Universidad de Cádiz,

Avda. Dr. Gomez Ulla, s/n, 11003 Cádiz (Spain),

mohand.tilmatine@uca.es

\section{Introduction}

Speaking about linguistic empires implies the existence of these empires and the role of language in their processes of territorial, economic and political expansion, but also the degree to which these empires used or use language as an instrument of power. The aim of this presentation is to take advantage of the theoretical debate about the role of powerful imperial languages in order to see if the observations or conclusions made for a language such as English or French can also be applied to other cases, generally less discussed. 
On this basis, this contribution will put into perspective a much less equal linguistic conflict than that of English and French, namely the conflict between Arabic and Berber.

1) In the case of Arabic and Berber, we are not speaking about a confrontation between two international languages of more or less equal value, but about a dominant, imperial language, Arabic. On the one hand, Arabic as a dominant language and on the other hand, Berber as a minoritised and subdominant language, - This situation can be described according to Swaan and Calvet's Gravitational system (Swaan 1993, Calvet 1999) or it can be analysed as one of the two strongest trends characterising current global linguistic dynamics: the displacement of minority languages and the expansion of English as the sole world language (Hamel, 2010).

2) Nevertheless, it seems that the several existing classifications do not perfectly correspond to the situation of Arabic and its relations with Berber in North Africa. In the best case, Arabic may be considered a language of rank 2, a "super central language" in the schema proposed by Hamel (2010: 6) and identified as such in Swaan (1993: 220), even if the definition (and the criteria of circles in extension) are not valid for Arabic. Berber, is also difficult to insert into the proposed schema.

From the point of view of its status and its social function, it may correspond to a "vernacular local language" of rank 6 in certain countries, but also to the category of "secondary central national language" in the fourth group in Hamel's schema. Taking forward the idea expressed by Hamel (2006a: 2247), it may be taken as symptomatic of the field that the authors of these theories writing about languages across the globe do so without taking into proper account such situations as those of Arabic or Berber.

In fact it is not possible to say that Arabic and Berber have a gravitational relationship because a language of a lower level - Berber in the present case gravitates around a language on the higher level - Arabic (Hamel 2006a: 2250). This is because, the authors do not specify which "Arabic" they are speaking about: the classical or the dialectal. If it is not classical Arabic, then which dialect among the numerous variants which exist in the so-called Arab Countries is being considered? Furthermore, if two Berber speakers meet, one a native of the northern littoral and the other one from further south, for example, and find it difficult to communicte in Berber, they will generally resort to the Arabic dialect, or even to another "super central language" such as French to communicate, but practically never to classical Arabic. Both Arabic and Berber have a certain relationship as a majority and dominant language vs. a minority and dominated language, but both also have independent lives and historic evolutions. 
However, the difficulty in figuring out the situation of both languages, Arabic and Berber, does not constitute the only difference with languages such as French and English. Speaking about Arabic and the empire created by the Muslims in the medieval period in comparison to modern colonial empires, certain divergences seem obvious.

3) First of all, a successful and massive spreading of the European colonial languages took place together with a massive emigration policy in the colonies and the extermination of their original populations. This happened foremost in the Americas where several countries were heavily settled by Europeans like the USA, Canada, Uruguay, Argentina, Brazil, Chile, Colombia, Venezuela, Costa Rica, Nicaragua and the Spanish Caribbean. Paraguay is considered to be the only country in the Americas which developed a collective bilingualism (Spanish and Guaraní) (Hamel 2006: 22). Contrary to this example, the extension of Arabic did not occur following massive emigration movements of native populations coming from the Arabian Peninsula towards North Africa.

4) In contrast to the main known historical case (the Roman Empire and the Latin language), Arabisation occurred with Arabic as the vehicle of a vast and fast campaign of Islamization. A very important difference between the situation of the so called "hypercentral" or "super central languages" such as English or French lies in the fact that the expansion of Arabic based itself fundamentally on the religion. This last point can be used as focus in this analysis and constitutes the basis of the Arabic domination in North Africa. This domination, which begins with the arrival of the Arabs and the Islamization of North Africa in the seventh century continued to present times by leaning on two fundamental pillars: on the one hand, Islamic legitimacy which fed off the inextricable relationship between Islam and Arabic, and on the other hand, nationalist legitimacy.

\section{Islamic legitimacy and Arabic: the sacred language}

Because of Muslim territorial expansion in the medieval period and the early and fast diffusion of Islam and the Qur'an, Arabic spread rapidly across the whole of North Africa. It is clear that Islam, being the religion of the vast majority of the North African population, played a significant role in the politics of Arabisation especially because of the very strong relationship between Islam and Arabic, its sacred language. The Qur'an often makes reference to the intimate relationship between the Arabic language and Islam, by these means con- 
ferring on it the sacredness about which we so often speak. (Arabic in the Qur'an (Source: Sahih International http://quran.com [20.02.2012]):

12: 2, Indeed, We have sent it down as an Arabic Qur'an that you might understand.

13:37, And thus we have revealed it as an Arabic legislation. And if you should follow their inclinations after what has come to you of knowledge, you would not have against Allah any ally or any protector.

16:103, And We certainly know that they say, "It is only a human being who teaches the Prophet.” The tongue of the one they refer to is foreign, and this Qur'an is [in] a clear Arabic language.

42: 7, And thus we have revealed to you an Arabic Qur'an [...].

43: 3, Indeed, We have made it an Arabic Qur'an that you might understand.

26: 195, In a clear Arabic language.

\subsection{Arabic-Islam: A long term relationship}

\subsubsection{Colonial empires and Arabisation policy}

This fact - the link between Islam and Arabic - has played a fundamental role in the so-called Arab-Islamic countries up until the present and it became the main cultural reference and maybe the most common feature of Arab identity in these countries, especially in North Africa. Contrary to a very wide-spread thesis, French colonialism across the Maghrib and the Spanish protectorate in northern Morocco did not develop a cultural policy in favour of the language of the Amazigh populations (Tilmatine 2011: 9-36).

In fact, it is important to underline that the Arabisation policy in independent North Africa was supported by France in the nineteenth century, before she became the region's colonial power. This idea took root so deeply in the population that it was able to survive during the colonial period. On this subject there is plentiful and important bibliography that I have neither the time, nor the space to explore fully. Nevertheless, I will mention briefly two factors which seem important to me.

\subsubsection{The project of an Arabic Empire and the Bureaux Arabes}

Much has been written on this unrealised project which was developed as part of French cultural policy in Algeria and aimed to create a client Arab empire under France's domination. Historians indicate that this political choice was supported or initiated in Napoleon III's time (Ageron 1970: 15). 
Abd el-Kader souverain d'un royaume arabe d'Orient, Abd el-Kader vice-roi ou gouverneur de Syrie, tels sont les thèmes d'une campagne politique qui se développa en France de 1860 à 1865 et même au-delà. Cette candidature était liée chez la plupart des publicistes et journalistes à l'idée d'une résurrection de l'empire arabe ou à l'affirmation des droits de la « nationalité arabe » [...] on a pu se demander s'il ne s'agissait pas d'une « idée napoléonienne », [...]. Bonaparte ayant été le premier parmi les chefs d'états occidentaux à avoir cru à la possibilité de faire renaître un empire arabe au milieu des ruines de l'empire ottoman, il n'est pas impossible que Napoléon III ait pensé qu'il était peut-être du destin des Napoléonides et de l'intérêt de la France d'aider à sa reconstitution

[Abd el Kader sovereign of an Arab kingdom in the Orient, Abd el Kader viceroy or governor of Syria, such are the themes of a political campaign which developed in France between 1860 and 1865 and even beyond. This candidacy was connected by most publicists and journalists to the idea of a resurrection of the Arab Empire or the affirmation of the rights of the Arab nation [...]. One may ask oneself whether it was not a 'Napoleonic idea', Bonaparte having been the first among the western heads of state to have believed in the possibility of reviving an Arab Empire in the midst of the ruins of the Ottoman Empire, it is not impossible that Napoleon III thought that it was perhaps the destiny of the Napoleonic Dynasty and in the interests of France to help in its reconstruction.]

French colonial policy, but also the Spanish Protectorate in northern Morocco intended, however, to encourage an Arabisation process by creating certain institutions such as the famous Bureau arabes (Yacono 1992) or by introducing other Arabisation programmes in northern Morocco, especially during the second part of the twentieth century.

\subsubsection{Spain's Arabisation policy in Northern Morocco}

From the beginning of their occupation of the North African territories France and then Spain attached great importance to the development of programmes of learning autochthonous languages and to the creation of structures in order to improve their knowledge of the mentality and of the psychology of the indigenous populations with the aim of putting them to the service of their different administrations.

Many individuals initiated their careers in the army where languages were taught. In addition to Arabic, classes in Amazigh language were given to military men and to other civil servants of the colonial governments. However, interest in Amazigh language was reduced actually to only one function: the acquisition of an instrument of communication or, according to Muñoz Bosque's expression ("Prologue": 5), to be a mode of "penetration into the heart of the local populations and their intimacy and confidence". 
The colonial powers were never interested in the Amazigh language as the native language of a population, nor in developing it in order to promote its role as a vehicle of expression, of education, of economy or, simply, of daily use. Education was carried out in Spanish, in French or in Arabic. Kabilian or Riffian Berber were never subjects of teaching; in no court was it possible to speak Amazigh; no journal or magazine was published in Amazigh throughout the whole colonial period that lasted 44 and 132 years in Morocoo and Algeria, respectively. On the contrary, the Arabisation of the Berber speaking areas began with the implantation of the so called "Bureaux arabes".

Arabic became an obligatory subject in secondary schools - for the Algerians who had access to education - and was even introduced by the White Fathers (Pères Blancs) before the Second World War in the schools. The situation in the north of Morocco during the Spanish protectorate was similar, and there, far from developing the Amazigh language, colonial policy always took the arabness of the country as a fundamental fact. The orientation of education in this region was always based on Arabisation which promoted elementary education in Arabic given mainly to Moroccan teachers.

An educational category that did not exist anywhere apart from the Spanish protectorate, emerged from the Schools of Teaching, centres where the trainee teachers received their instruction in Arabic was the Moroccan baccalaureate. This baccalaureate established following the Egyptian model, was unique to Morocco and it emerged in the context of an increasingly Arabic friendly political environment which favoured and stimulated natural evolution. (Valderrama 1956: 981-982)

The Spanish even favored running the administration in Arabic and also supported the teaching of Arabic in all the Schools of Trade in Spain, as well as in the Military and Naval Schools (Valderrama 1956: 909-910). It is worth noting that the first Algerian newspaper in Arabic was published by the French in 1847 (Le Mobacher) and continued appearing until 1926. To speak, in these conditions, of a policy that had favored the Amazigh element -- as it is frequently stated - can only be attributed to ignorance of such historical aspects, or, to the instrumentalization of politics.

\section{Nationalist legitimacy: Pan Arabism and Pan Islamism}

After the North African countries gained independence, the ideological choices of the new governments of these countries resulted in a policy of Arabisation of

Berber- speaking populations in Morocco, Algeria and Libya. Algerian leaders, 
especially the pan-Arab and pan-Islamist nationalists, soon adopted the famous

slogan from the Algerian 'alim (Islamic scholar) Ibn Badis: «L'islam est ma

religion, l'arabe est ma langue, l'Algérie est ma patrie» (Islam is my religion,

Arabic is my language and Algeria is my mother country). (Ageron 2002: 8)

This position contrasts however with the same author's perception of the Berber language. (Tilmatine 1997).

Since Classical Arabic is the language of the Qur'an throughout the Muslim speaking world and since language is an instrument of power, great campaigns of Arabisation were launched in order to replace French, the language of the colonizer, with Classical Arabic as the language of Arabo-Islamic identity. In this process, the influence of the Pan-Arabist Movement led by Michel Aflaq produced its effect by giving an important role to Arabic as common language for all the so-called Arab countries in their battle against European Colonialism. For the Algerian nationalists in the new Algerian government, Classical Arabic was the best vehicle of communication and instruction without which Algeria would probably lose its identity and values. Therefore Arabisation was considered to be one of the most important factors in restoring Algerian national identity and, of course, an essential ideological choice.

The fight against Colonialism, then, on the one hand, had to consist of a confrontation between Islam and Christianity, and on the other hand between Arabic and French. That is why one of the first decisions after Algerian independence in the early 1960s was the construction of a "national identity" which would only be possible through the "recuperation" of the Algerian character and the maintenance of the national unity of Algeria. The former President Boumedienne, one of the most fervent defenders of the Arabisation of Algeria, underlined this, saying:

Sans la récupération de cet élément essentiel et important qui est la langue nationale, nos efforts resteront vains, notre personnalité incomplète et notre unité un corps sans âme. (Mostari 2003: 26)

[Without recovering that essential and important element, the national language, our efforts will be in vain, our personality incomplete, and our unity a body without a soul.]

\subsection{Authoritarian Regimes after Independence}

After independence, the implementation of these ideological options, despite their lack of congruence with linguistic realities, was promoted by the new national independent governments: 
- The new North African States inherited from the colonial power, excessively centralised, authoritarian regimes

- $\quad$ Closed to any political, cultural or linguistic diversity

- An artificial national identity forged against colonialism and oriented exclusively towards eastern patterns of Pan-Arabism and Islamism

- Political spaces closed to any type of claims or demands, especially those concerning Kabylians.

Contradiction between Status and Corpus

- $\quad$ Founding Texts of the Nation States excluding Berbers

- Arabic as the only official national language

- Islam as State Religion

- Berbers without State support

- $\quad$ Berber confined to the field of orality

- $\quad$ Lack of expressive means to translate modern concepts

- Exclusion of Berber languages implies Identity Consciousness.

\subsection{Independence of North Africa: founding texts}

After the Algerian independence in 1962, the successive governments adopted radical measures by giving a central place to Arabic language and to Muslim religion in the founding texts of Algeria, even if they risked betraying the positions of the original Algerian revolution.

Indeed, the Algerian Revolution respected certainly Islam as a majority religion in Algeria, but without granting a fundamental role to it in the ideology of a National Liberation Movement, which was rather inspired by Marxism.

"One of the striking features " according to R. Letourneau (1968: 158), "is the secularization of the Algerian State. It is not that the new regime attacks Islam, but, whether it concerns the constitution or the congress, Islam plays a very low profile role in Algeria".

In this sense, one of the most important reference texts of the Algerian Revolution, the Soummam Platform, underlines that "The demarcation line of the Revolution does not pass among the religious communities in Algeria ", and criticizes at the same time "the French imperialism which fought the progressive movement of the Oulémas (Islamic Scholars) ${ }^{1}$.

\footnotetext{
${ }^{1}$ La Plateforme de la Soummam. This document is available on the Web site of the Algerian Government: http://www.el-mouradia.dz/arabe/symbole/textes/soummam.htm.
} 
However, as in many other cases, these political principles would change rapidly after the independence of the country which will opt immediately for their anchoring in the founding texts of the new Algerian Republic.

Algeria: Constitutions of 1963 and of 1976

- $\quad$ Art. 2: Algeria is an integral part of the Arab Maghreb, the Arab world and Africa

- $\quad$ Art. 4: Islam is the religion of the State..

- Art. 5: The Arab language is the national and official language of the

State

- $\quad$ Constitution of 23 February1989:

- $\quad$ Art. 3: The Arabic language is the national and official language $>10$ April $2002>$ 3bis: «Tamazight is also national language».

Tunisia (1995) \& Morocco (1996)

- $\quad$ Art. 1. - Tunisia [...]; its religion is Islam, its language is Arabic.

- $\quad$ Art. 2. - The Republic of Tunisia constitutes a part of the Great Arab Maghreb

- $\quad$ The Kingdom of Morocco, sovereign Moslem State, whose official language is Arabic, constitutes a part of the Great Arab Maghreb "Grand Maghreb'.

- $\quad$ Art. 6. - Islam is the Religion of the State.

- $\quad$ Art. 5 (Morocco's Constitution of 2011):

L'arabe demeure la langue officielle de l'État. L'État œuvre à la protection et au développement de la langue arabe, ainsi qu'à la promotion de son utilisation. De même, l'amazighe constitue une langue officielle de l'État, en tant que patrimoine commun à tous les Marocains sans exception.

[Arabic remains the official language of the State. The State works for the protection and for the development of the Arabic language, as well as the promotion of its use. Also, Amazigh constitutes an official language of the State, as a common heritage for all Moroccan people without exception (own translation).] 


\subsection{Laws of Arabisation to restore the "former" and "lost" language}

The main tenet of Algerian identity was that Algeria inherited a French linguistic legacy of 132 years and that the Arabisation process would change that situation and "restore" the "lost" national language.

Immediately after independence several laws, decrees and ordinances were enacted, reinforced and applied aiming at implementing Classical Arabic and strengthening its position in all public domains. French had to be reduced to a foreign language as soon as possible.

This policy clashed first with the Francophone and particularly the Berber section of the Algerian population who gave priority to development issues and regarded Classical Arabic as an outdating language which could not cope with modernity and technology, while the defenders of Classical Arabic considered it an integrative and essential component of the Algerian personality.

\subsubsection{Arabisation in public administration}

Arabisation campaigns were launched in several domains, notably the administration, environment and education. President Boumedienne (19651978) attempted to achieve a radical and effective Arabisation of public administration. A decree from 1968 states:

Dans un délai de trois ans, les fonctionnaires doivent apprendre suffisamment d'arabe pour travailler dans cette langue [In a period of three years, functionaries should learn enough Arabic to work in this language]. (Grandguillaume 1997: 03).

\subsubsection{The 1991 Law of Arabisation}

An extreme example of this policy of total Arabisation was the promulgation of Law number 91-05 of 16 January 1991. On December 26, 1990, the Popular National Assembly of Algeria had voted for a law of Arabisation. According to this law, the administration was to be totally arabized by 5 July 1992, and tertiary education was to be Arabized by 1997 (Djité 92: 15).

On 17 December 1996, the Algerian government (Conseil National de Transition, Algerian Transitional National Council) voted unanimously to adopt a law on the "generalization of the use of the Arabic Language" which stated that: 
Les administrations publiques, les institutions, les entreprises et les associations quelle que soit leur nature sont tenues d'utiliser la seule langue arabe dans l'ensemble de leurs activités telles que la communication, la gestion administrative, financière, technique et artistique

[All public administration, institutions, enterprises and associations, of whatever nature, are required to use only the Arabic Language in all their activities, including communication and administrative, financial, technical and artistic management.]

The act also specified that, "The use of any foreign language in the deliberations and discussions of official meetings is forbidden”.

\subsubsection{Guidance Law of Education (2008) ${ }^{2}$}

The values defended by the Pan-Arabist and Pan-Islamist activists were also reflected in the text of a law concerning the Algerian educational system.

In the years immediately following independence, teachers were trained hastily or recruited abroad (particularly from Middle Eastern countries like Egypt, Syria and Iraq).

During the mid-1970s, the Algerian authorities approved a great number of reforms concerning the educational system at primary, secondary and university levels. In order to quicken the Arabisation process and achieve a total Arabisation of education from the primary to secondary levels, all teacher training centres were Arabized.

According to the ideology of the Algerian Ulema (Islamic scholars), the new Algerian government considered the educational system to be the most strategic instrument in order to recover the Algerian personality and identity.

The Guidance Law of 2008 underlined again that Islam was the fundamental basis of that Algerian identity:

Les caractéristiques de la nation algérienne ont été ainsi façonnées par l’Islam qui a conféré au peuple algérien la dimension fondamentale de son identité. (p.7).Le peuple algérien a assimilé effectivement l'Islam en tant que religion avec son système de valeurs morales et spirituelles et en tant que modèle d'organisation sociale (p.8).

[The characteristics of the Algerian nation have been defined by Islam which has conferred on the Algerian people the fundamental aspect of its identity. (p. 7). IN effect, the Algerian people have assimilated Islam both as a religion with a system of moral and spiritual values and as a model of social organization (p. 8).]

2 Loi d'orientation sur l'éducation nationale $\mathrm{N}^{\circ} 08$ - 04 du 23 janvier 2008 http://static.blog4ever.com/2006/01/73270/artfichier_73270_96605_201004130729864.pdf. 
The law also cited attachment to Islam and its fundamental basis, Arabic:

Tels sont les idéaux pour lesquels le peuple algérien s'est toujours mobilisé à travers son histoire : l'attachement à l'Islam et aux valeurs de la civilisation arabo-musulmane avec sa composante fondamentale qui est la langue arabe (p.8) [Such are the ideals for which the Algerian people have always mobilized through history: attachment to Islam and to the values of Arabo-Islamic civilization and its fundamental component, the Arabic language (p. 8).]

Or the promotion of the Arabic language as a factor in the "recovery" of the Algerian personality:

La promotion de l'enseignement de la langue arabe en tant que langue nationale et officielle et facteur de recouvrement de la personnalité algérienne sera consolidée et renforcée dans le cadre de la politique rénovée de l'éducation nationale (p. 9) [The promotion of the teaching of Arabic language both as a national and official language and as a factor in the recovery the Algerian personality will be consolidated and reinforced within the framework of the renewed policy of national education. (p. 9)]

\section{Arabic: from a language of empire to a language of domination}

Arabic shares with French and especially English some features of an imperial language: it was used to support an empire which expanded over the territory now divided between a large number of states on three continents. The difference is, however, in the legitimacy of this domination which changed in the case of the British and French empires from violent military domination to economic domination. This is especially the case for English with its hegemonic position (hypercentral language). In contrast, Arabic's dominance is legitimized by two fundamental pillars: religion, which has used Arabic as the sacred language of the Qur'an for centuries and then nationalism which decreed that "Arabic" was a unique national language at the birth of the North African nation-states.

Arab nationalist revolutionary legitimacy justified a vast policy of Arabisation and produced a legal arsenal to impose it on the population. The 1991 law of Arabisation discussed in this contribution is an example.

In fact, successive Algerian governments undertook the task of reviving Classical Arabic and establishing it as the national language of Algeria. The aim was to recover an "imagined" pre-colonial past and eventually to restore the national identity and Arab personality of the newly independent nation. 


\subsection{Repression and discrimination}

To establish and impose these ideological choices, repressive laws were proclaimed after independence to force the process of ArabiArabisationsation upon local populations and to break their resistance in flagrant violation of the international laws which protect linguistic rights. Cultural and linguistic discrimination in Morocco and in Algeria exists in the form of repressive measures against Berber activists, their detention, the non-recognition of Berber names, the refusal to recognize the Berber New Year Yennayer as a holiday or generally, especially in recent years, as the persecution of Kabylian Christians, among others.

The policy of Classical Arabic implementation was supported by the vast majority of Algerians. Nevertheless, since the Arabisation project does not allow the Berber language to play any role, the Berbers, especially the Kabylians, have intensified their efforts to slow down if not to halt the Arabisation campaigns.

The policy has thus led to conflict within Algerian society, and to the questioning of the ideological posture asserting the unity and the homogeneity of the nation.

On one hand, there is a Berber movement, allied to the Francophone sector of society, known as the "France-Party"; on the other hand, there is a group with a more traditionalist orientation which is closer to Islamist ideas. These two groups fight for different visions of society and are characterized by Djaout as, "La famille qui avance et la famille qui recule" (The family which moves forward and the family which moves back) (Djaout 1993).

\subsection{Self-hate and identity crisis}

The absolute domination of Arabic, as a "language of bread" (Native language), inculcated in speakers of other autochthonous languages is reflected in some situations including patterns of self-hate and linguistic alienation. Intense campaigns of belittlement were targeted against Amazigh activists. They were accused of separatism and of being part of the pro-French Party (Hizb Fransa). The most radical fringes of the Algerian political scene, in particular the Islamists, have not hesitated to compare the Berber movement with those whom they consider the vilest enemy, the Jews. 


\subsection{Berbers and Jews}

The Moroccan newspaper Anoual OADP-Party ${ }^{3}$ ) published a series of articles by Othman Saadi (Cf. Number 11, 15 February 1996) who wrote:

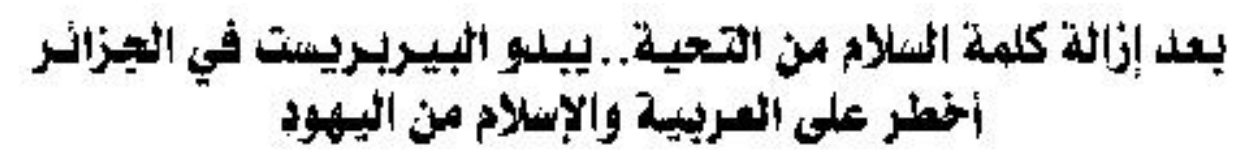

(After the abolition of the word 'al-Salam' as greeting formula, Berberism in Algeria can be considered more dangerous to Arabic and Islam than the Jews).

As usual this attitude only encourages the spiral of violence and strengths the Amazigh movement which has existed since the early 1980s.

This movement started in Tizi Ouzou, the capital of the Kabylian region in Algeria, from where it spread throughout other Berber-speaking regions. Since the 1990s it has not stopped growing and it has obtained a measure of recognition for Berber as a national and official language in Algeria (2001) and Morocco (2011) respectively.

Since the events of the "Arab Spring", other berberophone countries as Tunisia and especially Libya joined this movement, supporting its claims and acting on the international scene.

\section{References}

Ageron, Charles-Robert (1970): Abd el-Kader souverain d'un royaume arabe d'Orient, in: Revue de l'Occident musulman et de la Méditerranée 8, 15-30.

Ageron, Charles-Robert (2002): "L'Algérie est ma patrie » Naissance d'une nation, in: Les Collections de l'Histoire 15, 8. 07/03/2002. http://www.histoire.presse.fr/lescollections-de-lhistoire/ 15/lalgerie-est-ma-patrie-07-03-2002-10355 (checked 12/03/2011).

Benrabah, Mohamed (1999): Langue et pouvoir en Algérie Histoire d'un traumatisme linguistique. Paris: Séguier, Les Colonnes d'Hercule.

Benrabah, Mohamed (1993): La haine de soi (1ère partie), in: Ruptures (hebdomadaire algérien) 18, 11-17 mai 1993, 22-23; La haine de soi (2ème partie), in: Ruptures (hebdomadaire algérien) 19, 18-24 mai 1993, 22-23.

Bouhania, B. (1999): The substitution of French loan words for Arabic counterparts in Oran Arabic: a case study. Unpublished Magister Thesis. Oran: University of Arts and Letters.

Calvet, Louis-Jean (1999): Pour une écologie des langues du monde. Paris: Plon.

3 The Organization of the popular democratic action (OADP) was a Moroccan political party funded by Mohammed Bensaid Ait Idder in 1983; it was replaced by the Unified Socialist Party. 
Coste, Daniel (1984): Aspects d'une politique de diffusion du français langue étrangère depuis 1945, matériaux pour une histoire. Paris: Hatier.

Crystal, David (2000): Language death. Cambridge: Cambridge University Press.

Dajout, Tahar (1993): La famille qui avance et la famille qui recule, in: Ruptures 20 (25-31 mai), Chromique.

Djité, Paulin (1992): The arabization of Algeria: linguistic and sociopolitical motivations, in: International Journal of the Sociology of Language 98, 15-28.

Gasquet-Cyrus Mederic \& Cécile Petitjean (eds.) (2009): Le poids des langues. Paris: l'Harmattan.

Gobard, Henri (1976): L'aliénation linguistique: analyse tétraglossique. Préface de Gilles Deleuze. Paris: Flammarion.

Grandguillaume, Gilbert (1997): Arabisation et démagogie en Algérie, in: Le Monde diplomatique, 515, 3.

Grandguillaume, Gilbert (1983): Arabisation et politique linguistique au Maghreb. Paris: Éditions Maisonneuve et Larose.

Haeri, Niloofar (2003): Sacred language, ordinary people. Dilemmas of culture and politics in Egypt. New York: Palgrave.

Hagège, Claude (2000): Halte à la mort des langues. Paris: Odile Jacob.

Hamel, Enrique R. (2010): L'aménagement linguistique et la globalisation des langues du monde, in: Télescope 16(3), 1-21.

Hamel, Enrique R. (2006): Sprachimperien, Sprachimperialismus und die Zukunft der Sprachenvielfalt, http://www.goethe.de/lhr/pro/mac/Online-Publikation.pdf; 1546.

Hamel, Enrique R. (2006a): The development of Language Empires, in: Ulrich Ammon; Dittmar, Norbert; Mattheier, Klaus J. \& Trudgill, Peter (eds.), Sociolinguistics. Soziolinguistik. An international handbook of the science of language and society, vol. 3. Berlin, New York: Walther de Gruyter, 2240-2258.

Letrouneau, Roger (1968): La révolution algérienne, in : Revue de l'Occident musulman et de la Méditerranée 5, 153-160.

Lorcin, Patricia M. E. (1995): Imperial Identities: Stereotyping, Prejudice and Race in Colonial Algeria, Londres y Nueva York, I.B. Tauris.

Miller Catherine (2009): Le poids de l'arabe mais de quel arabe parlons-nous?, in: Mederic Gasquet-Cyrus \& Petitjean, Cécile (eds.), Le poids des langues. Dynamiques, représentations, contacts, conflits. Paris: l'Harmattan, 141-162

Mostari, Hind A. (2003): Arabization and language use in Algeria, in: Journal of Humanities 17, 26-41.

Ostler, Nicholas (2006): Empires of the word: a language history of the world. London: Harper Perennial.

Phillipson, Robert (2009): Linguistic imperialism continued. New York and London: Routledge.

Rey-Goldzeiguer, Annie (1977): Le royaume arabe. La politique algérienne de Napoléon III, 1861-1870. Alger: SNED.

Swaan, Abram de (2001): Words of the world: the global language system. Cambridge: Cambridge University Press.

Swaan, Abram de (1993): The emergent world language system: an introduction, in: International Political Science Review 14(3), 219-226. 
Tilmatine, Mohand (2012): Berber and Arabic language contacts, in: Weninger, Stefan (in collaboration with Geoffrey Khan, Michael P. Streck and Janet C. Watson) (eds.), An international handbook on their structure, their history and their investigation. Berlin/Boston: Walter de Gruyter, 1001-1014.

Tilmatine, Mohand (2011): La política cultural durante el protectorado español en Marruecos: el caso del Bereber, in: Signos Lingüísticos 5(9), 9-36

Tilmatine, Mohamed (1997): Les Oulémas algériens et la question berbère, un document de 1948, in: Awal 15, 77-90.

Valderrama, Martínez, Fernando (1956): Historia de la acción cultural de España en Marruecos (1912-1956). Tetouan.

Yacono, Xavier (1992): Bureaux arabes, in: Encyclopédie Berbère 11, Aix-en-Provence, 1657-1668. 